\title{
PENGOLAHAN LIMBAH JERAMI PADI MENJADI PELET IKAN MAS (Cyprinus Carpio) DI DESA HAREAN PORSEA KABUPATEN TOBA SAMOSIR
}

\author{
Rita Juliani $^{1 *}$, Friscylia Tampubolon', Sri Ratika Samosir ${ }^{1}$, Mariana Simangunsong ${ }^{2}$, \\ Laurenchus Manurung ${ }^{3}$
}

\author{
${ }^{1}$ Jurusan Fisika, Fakultas Matematika dan Ilmu Pengetahuan Alam, Universitas Negeri Medan, Medan, Indonesia \\ ${ }^{2}$ Jurusan Biologi, Fakultas Matematika dan Ilmu Pengetahuan Alam, Universitas Negeri Medan, Medan, Indonesia \\ ${ }^{3}$ Jurusan Elektro, Fakultas Teknik, Universitas Negeri Medan, Medan, Indonesia \\ Penulis Korespondensi: julianiunimed@gmail.com
}

\begin{abstract}
Abstrak
Desa Harean adalah salah satu desa di kecamatan Porsea yang berada di pinggiran Danau Toba. Mata pencaharian masyarakat sebagian besar bertani padi dan budidaya ikan mas. Budidaya ikan mas membutuhkan pakan berupa pelet yang dibeli di pasar sedangkan hasil bertani padi setiap tahun menghasilkan limbah jerami yang dapat di manfaatkan menjadi pelet. Tujuan dari kegiatan PKM-T membantu mitra membuat pelet ikan mas dari limbah jerami padi dan mendesain mesin dwi fungsi untuk membantu pengolahan pembuatan pelet. Metode yang digunakan melalui beberapa tahap, yaitu sosialisasi, pendampingan, monitoring dan evaluasi. Sosialisasi dilakukan dengan menyampaikan pengetahuan mengenai manfaat dari limbah jerami yang dapat di jadikan pakan ikan mas. Pendampingan pembuatan pelet ikan mas dari jerami dilakukan dengan cara memfermentasi jerami dengan larutan Molase dan EM 4 selama 21 hari, kemudian menghaluskan jerami dan mencampurkan dengan dedak, keong mas dan tepung ikan dengan menggunakan mesin dwi fungsi untuk penggilingan dan pencetakan pelet. Hasil monitoring dan evaluasi mitra mampu membuat pelet ikan mas sebagai pengganti pakan ikan yang di beli di pasaran dengan menggunakan mesin dwi fungsi.
\end{abstract}

Kata Kunci : Harean, Ikan mas, Jerami padi, Pelet

\begin{abstract}
Harean is one of the villages in Porsea regency on the outskirts of Lake Toba. The livelihood of the community is mostly rice farming and goldfish cultivation. Goldfish farming requires feed in the form of pellets purchased in the market while the yield of rice farming every year produces straw waste which can be used as pellets. The purpose of PKM-T activities was to help partners making goldfish pellets from rice straw waste and design bi-function machines to assist pellet-making processing. The method used through several stages, namely socialization, mentoring, monitoring and evaluation. The socialization was carried out by conveying knowledge about the benefits of straw waste which could be made into goldfish feed. Assistance for making pellets from straw was carried out by fermenting straw with Molasses and EM 4 solution for 21 days, then smoothing the straw and mixing it with bran, golden snails and fish powder using a dual function machine for milling and printing. The results of the monitoring and evaluation of partners were able to make carp pellets as a substitute for fish feed purchased on the market using dual function machines.
\end{abstract}

Keywords: Harean, Goldfish, Rice straw, Pellet

\section{PENDAHULUAN}

Masyarakat desa Harean di kecamatan Porsea mayoritas bermatapencaharian sebagai petani padi dan budidaya ikan mas. Petani dalam hal ini mitra menanam padi 1-2 kali pertahun. Mitra setiap panen padi menghasilkan limbah jerami yang biasanya dibuang atau dibakar. Limbah jerami yang dihasilkan belum dimanfaatkan secara maksimal (Marta, 2003). Jerami adalah bagian vegetatif tanaman padi (batang, daun, tangki malai) yang tidak dipungut saat tanaman padi dipanen. Kandungan hara jerami padi bergantung pada kesuburan tanah, jumlah pupuk yang diberikan, kualitas dan kuantitas air irigasi, dan iklim (Balai Penelitian dan Pengembangan Pertanian, 2007). Jerami merupakan bahan organik yang tersedia dalam jumlah yang signifikan bagi petani padi. Sekitar $40 \%$ $\mathrm{N}, 30-35 \% \mathrm{P}, 80-85 \% \mathrm{~K}$, dan $40-50 \% \mathrm{~S}$ tetaap dalam sisa bagian vegetatif tanaman. Jerami 
merupakan sumber hara mikro penting seperti seng (Zn) dan silikon ( $\mathrm{Si}$ ) (Dobermann and Fairhurst, 2002). Mitra tidak memanfaatkan limbah jerami karena minimnya pengetahuan mitra dalam mengolah jerami padi serta tidak adanya alat yang dapat membantu mitra dalam mengolah limbah jerami padi (Awaluddin, 2010).

Budidaya ikan mas yang dikelola oleh mitra merupakan jenis ikan yang banyak diminati. Produksi ikan mas rata-rata setiap tahun mulai 2010-2014 sebesar 14,44\%. (Direktorat Jenderal Perikanan Budidaya, 2014). Budidaya ikan mas memerlukan pakan baik secara alami maupun buatan. Pakan alami merupakan pakan hidup, mencakup fitoplankton, zooplankton, dan benthos yang telah tersedia secara alami di alam, baik dengan atau tanpa bantuan manusia. (Herawati \& Agus, 2013). Pakan alami kurang memadai jumlahnya untuk perkembangan budidaya ikan mas karena jumlahnya tidak mencukupi sehingga perlu pengadaan pakan buatan untuk budidaya ikan mas. Tim PKM-T memunculkan gagasan untuk mengolah jerami padi menjadi pelet yang bermanfaat untuk mitra. Pelet ikan jerami merupakan inovasi untuk membantu mitra dalam membudidayakan ikan mas yang lebih alami dan memiliki harga yang ekonomis. Tujuan kegiatan untuk membantu mitra dalam memenuhi kebutuhan pakan ikan dengan harga yang lebih terjangkau, memberikan solusi untuk membuat pelet sendiri dari jerami padi dan meningkatkan nilai guna dan ekonomis jerami

Pembuatan pelet dari jerami dimulai dengan fermentasi dan kemudian di campurkan dengan tepung keong mas yang berasal dari keong mas yang ada di sekitar persawahan serta dedak untuk melengkapi nutrisi bagi ikan mas. Untuk mempermudah pembuatan pelet jerami padi Tim merancang mesin yang dapat digunakan untuk menghaluskan jerami dan keong mas menjadi tepung dan mencetak pelet yang disebut dengan mesin dwi fungsi. Produksi mesin dwi fungsi yang dihasilkan akan membantu mitra dalam proses pembuatan pakan ikan mas . (Sarwono dan Arianto, 2003).

\section{BAHAN DAN METODE}

\subsection{Bahan}

Bahan yang di gunakan dalam pembutan pelet ikan mas tertera pada Tabel 1

Tabel 1. Bahan yang digunakan untuk pelet ikan

\begin{tabular}{|c|c|}
\hline No & Bahan Pembuatan Pelet \\
\hline $\mathbf{1 .}$ & Jerami \\
\hline $\mathbf{2 .}$ & Dedak \\
\hline $\mathbf{3 .}$ & Keong Mas \\
\hline $\mathbf{4 .}$ & EM4 \\
\hline $\mathbf{5 .}$ & Gula \\
\hline
\end{tabular}

\subsection{Metode}

Metode yang digunakan dalam kegiatan dimulai dari tahap wawancara, sosialisasi, pendampingan, monitoring dan evaluasi. Tahapan pelaksanaan program tertera pada Gambar 1 :

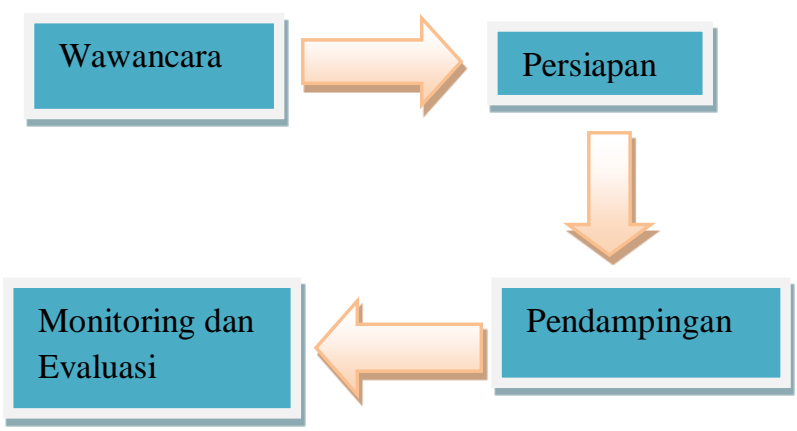

Gambar 1. Tahapan Kegiatan Pelaksanaan Program PKM-T

Tahap wawancara dilakukan dengan mitra untuk mengetahui permasalahan berupa harga pakan ikan mas yang terus meningkat. Persiapan penyediaan alat dan bahan yang dibutuhkan dalam kegiatan berupa bahan baku pelet. Pendampingan dilaksanakan agar mitra mampu membuat pelet ikan mas dan menggunakan mesin dwi fungsi yang dirancang oleh Tim. Monitoring dan evaluasi dilakukan untuk mengetahui ketermanfaatan program PKM-T pada mitra dan umpan balik yang diberikan. Pelaksanaan kegiatan pembuatan pelet dari limbah jerami tertera pada Gambar 2.

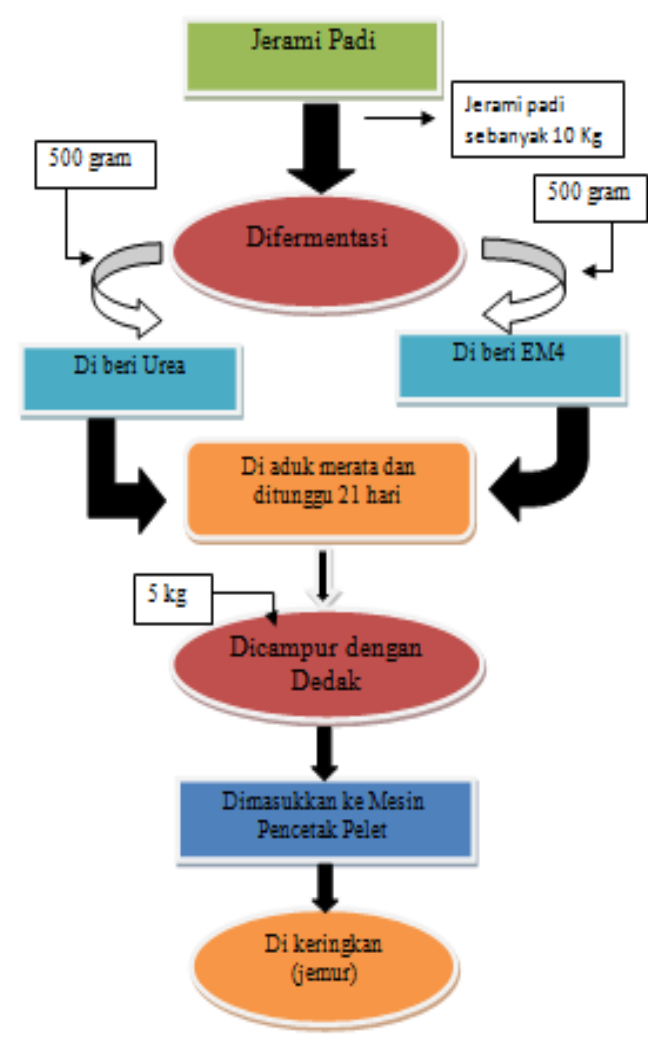

Gambar 2. Diagram Pembuatan Pelet Ikan Mas Dari Jerami 


\section{HASIL DAN PEMBAHASAN}

Pendampingan pembuatan pelet ikan mas dilakukan dengan cara memfermentasi jerami padi untuk meningkatkan kadar protein dan mengurangi kadar serat. Jerami dicampurkan EM4 dan Molase secara merata kemudian di simpan selama 21 hari di tempat yang bebas dari cahaya maupun udara (Juliani, dkk. 2017). Jerami yang difermentasi menghasilkan jerami dimana serat kasarnya telah berkurang serta struktur dari jerami menjadi lebih ringan namun tidak membusuk sesuai dengan gambar 3 .
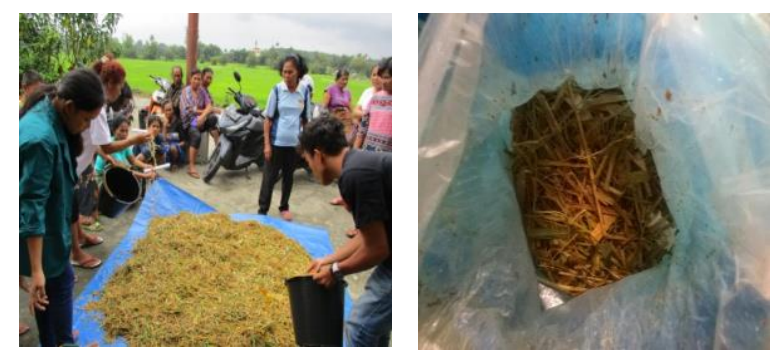

Gambar 3. Proses Fermentasi

Pembuatan pelet ikan mas, memerlukan sumber protein dan kalsium yang diperoleh dari keong mas. Keong mas diambil dari sawah mitra dengan memanfaatkan sistem penangkapan menggunakan dedaunan. Keong mas direbus untuk mempermudah pemisahan daging dan cangkang. Daging dan cangkang di keringkan (Gambar 4). Tujuan dari pengeringan untuk mengurangi kadar air yang terdapat pada daging dan cangkang keong, selanjutnya dilakukan proses penggilingan daging dan cangkang dari keong untuk menghasilkan tepung protein dan kalsium.

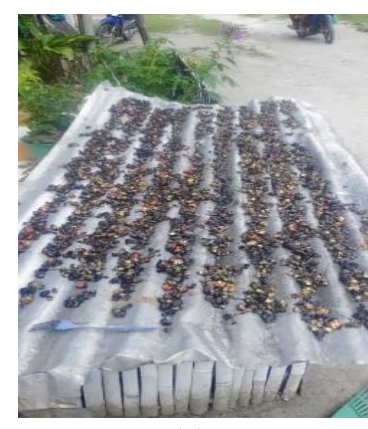

(a)

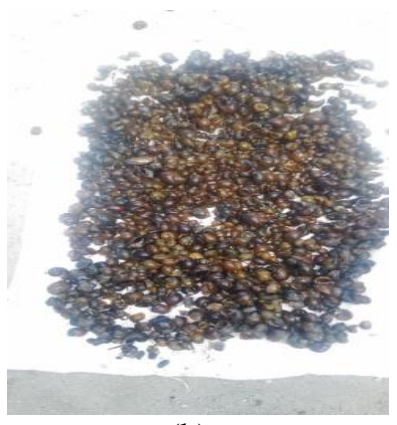

(b)
Gambar 4. Pengeringan daging (a) dan pengeringan cangkang keong (b)

Jerami yang telah difermentasi, dihaluskan dan dicampur dengan dedak, tepung daging dan cangkang keong dengan menggunakan mesin dwi fungsi. Semua bahan dicampur hingga halus dan selanjutnya dicetak dengan menggunakan mesin pencetak pelet (Gambar $5)$.

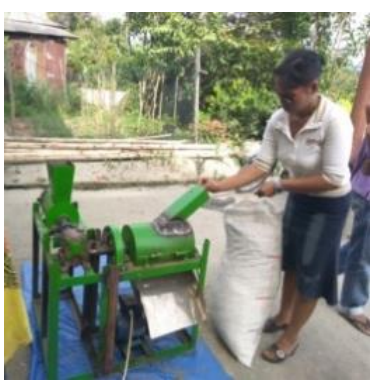

(a)

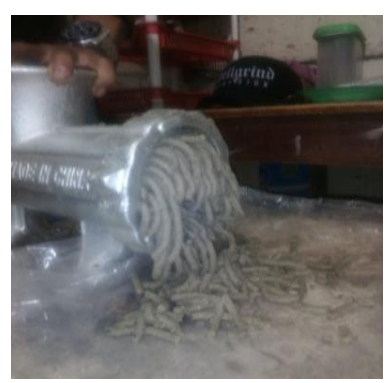

(b)
Gambar 5. Penggilingan jerami menggunakan mesin dwi fungsi (a) dan pencetakan pelet (b)

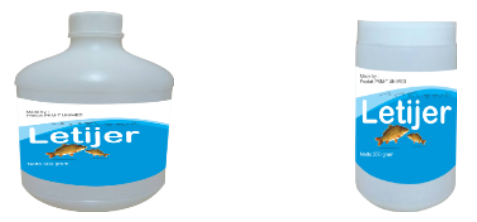

Gambar 6. Hasil Produksi Pelet Ikan Mas

Pelet yang telah dihasilkan di jemur untuk mengurangi kadar air pelet. Setelah proses penjemuran selesai, pelet siap untuk dipakai sebagai bahan pakan ikan mas yang alami dengan harga terjangkau.

Keunggulan pelet ikan mas dari jerami adalah tersedianya bahan baku dan tambahan berupa jerami dan keong mas serta dedak. Produk pelet ikan jerami (Letijer) dikemas dalam ukuran 250 gram dan 500 gram serta $1 \mathrm{~kg}$. Komposisi pelet ikan mas dari jerami, yang di hasilkan di uji di Balai Riset Dan Standarisasi Industri (BARISTAND) Medan dan di bandingkan dengan prasyarat pelet untuk ikan tertera pada Tabel 2 .

Tabel 2. Komposisi Pelet Ikan

\begin{tabular}{|l|l|l|l|l|}
\hline No. & \multicolumn{1}{|c|}{ Parameter } & Satuan & $\begin{array}{c}\text { Standar } \\
\text { Mutu }\end{array}$ & $\begin{array}{c}\text { Hasil } \\
\text { Uji }\end{array}$ \\
\hline 1 & Kadar Air & $\%$ & $11-13$ & 14.5 \\
\hline 2 & Protein & $\%$ & $28-30$ & 11.3 \\
\hline 3 & Lemak & $\%$ & $4-16$ & 13.7 \\
\hline 4 & Karbohidrat & $\%$ & $25-35$ & 30.9 \\
\hline 5 & Posfor $\left(\mathrm{P}_{2} \mathrm{O}_{5}\right)$ & $\%$ & 3 & 2.59 \\
\hline 6 & Kalsium $(\mathrm{Ca})$ & $\mathrm{mg} / \mathrm{kg}$ & & 834 \\
\hline
\end{tabular}

\section{KESIMPULAN}

Limbah jerami padi termanfaatkan menjadi pelet ikan mas yang mengandung protein, lemak, karbohidrat posfor dan kalsium. Pelet bermanfaat bagi mitra untuk membudidayakan ikan mas. Pelet yang dihasilkan mengurangi pengeluaran mitra dalam pembelian pelet ikan di pasar .

\section{UCAPAN TERIMA KASIH}

TIM berterima kasih kepada RISTEKDIKTI yang mendukung kegiatan dan mendanai kegiatan PKM-T, Universitas Negeri Medan, mitra di desa Harean Porsea, serta kepada ibu Dosen Pendamping yang 
telah membimbing terlaksananya kegiatan, dan buat semua pihak yang telah mendukung.

\section{DAFTAR PUSTAKA}

Awaluddin, 2010. Sistem Integrasi Padi - Ternak, Balai Pengkajian Teknologi Pertanian (BPTP) Sulawesi Selatan, Makassar, (Kamis, 20 Oktober 2011).

Balai Penelitian dan Pengembangan Pertanian. 2007. Jerami Padi : Pengelolaan dan Pemanfaatan. Bogor.

Direktorat Jenderal Perikanan Budidaya.2014. Laporan Kinerja Direktorat Jenderal Perikanan Budidaya. Jakarta : Kementrian Kelautan dan Perikanan.

Dobermann A., Fairhurst TH. 2002. Rice Straw Management Better Crops International. 16.

Herawati V.E. \& Muhammad A. 2013. Analisis Pertumbuhan dan Kelulushidupan Larva Lele (Clarias gariepinus) yang Diberi Pakan Daphnia sp. Hasil Kultur Massal Menggunakan Pupuk Organik Difermentasi. Jurnal Rekayasa dan Teknologi Budidaya Perairan. Vol.VI, No.1.

Juliani R, Simbolon R, Sitanggang W, Aritonang J. 2017. Pupuk Eceng Gondok Dari Danau Toba. Jurnal Pengabdian Kepada Masyarakat. Vol.23, No.1.

Marta W. U., 2003. Pemanfaatan Jerami Padi Sebagai Pengganti Rumput Untuk Ternak Ruminansia Kecil, Jurnal Wartazoa Vol. 13 No. 3 Th. 2003.

Sarwono, W. Dan Arianto. 2003. Manajemen Pemeliharaan Sapi Potong. Penebar Swadaya : Jakarta 